Egyptian Journal of Aquatic Biology \& Fisheries

Zoology Department, Faculty of Science,

Ain Shams University, Cairo, Egypt.

ISSN 1110 - 6131

Vol. 22(5): 175- 187 (2018)

ejabf.journals.ekb.eg

\title{
Histochemical and fine structure studies of pituitary cell type distribution with special emphasis of gonadotrophs during annual reproductive cycle of the adult female white seabream (Diplodus sargus)
}

\author{
Rania. F. Ismail and Reham. M. K. Negm \\ Laboratory of Fish Reproduction and Spawning, Aquaculture Division, National Institute of \\ Oceanography \& Fisheries, Kayet-bey, Alexandria, Egypt.
}

\section{ARTICLE INFO \\ Article History: \\ Received: Sept.19,2018 \\ Accepted:Oct.28,2018 \\ Available online:Nov. 2018}

\section{Keywords:}

Pituitary gland

Histochemistry

electron microscope

reproductive cycle

Diplodus sargus

\begin{abstract}
The ovarian cycle of the female white seabream (Diplodus sargus) can be explained as five stages as follows: Immature, Maturing, Nearly ripe , Ripe and Running and Spent stage, whereas the peak of gonadostmatic index was reported between January to April, with an average GSI value of $2.64 \pm$ 0.6. The adenohypophysis of white seabream was investigated using histochemical and electron microscopy techniques. It can be subdivided into three distinct regions: rostral pars distails (RPD), proximal pars distails (PPD) and pars intermedia (PI). Six cell types were identified and localized in the adenohypophysis. The acidophilic prolactin (PRL) and adrenocorticotropic hormone secreting cell (ACTH) were found in the RPD region. The ACTH cells were generally arranged between neurohypophysis and PRL cells. The melanocyte stimulating hormone secreting cells (MSH) and somatotrops cells (STH) were acidophilic and detected in the PPD and RPD regions. The basophilic cells were gonadotrophic cells (GTH) and the thyrotrophic cells (TSH); one type of the GTH cells was detected in D. sargus pituitary. The GTH cells displayed variations through the reproductive cycle, while all four types of acidophilic cell and TSH cells did not show any variations in size and activity throughout the reproductive cycle. During immature and mature stages GTH cells showed the minimum granulation and smaller cell size, at nearly-ripe stage the GTH cells were characterized by intense accumulation of granules and reached to maximum diameters $(p<0.05)$ as demonstrated by electron microscope. During ripening and running stage (from January to April), slight decrease in the GTH cell diameters and its staining affinity and granulation were observed. During the spent stage (from April to June) the GTH cells displayed faint stain with presence of vacuoles between cells with minimum amount of granulation.
\end{abstract}

INTRODUCTION

The white seabream Diplodus sargus (Linneaus, 1758) is one of the commercial marked species in the Mediterranean countries (FAO, 2014; Veiga et al., 2010). Moreover, it is appropriate species for aquaculture. Yet, there have been a very few studies on the white seabream culturing even though its importance as members of the Sparidae family. The correct determination of the species spawning period, sex-ratio, GSI, length at first maturity and hormonal activity are the main required data for any cultured species. 
The hormones produced by pituitary gland of teleosts regulate directly/indirectly some fundamental physiological processes like growth, development, reproduction and stress responses (Schreibman, 1986; Agulleiro et al., 2006). Taking into account the role of the physiological processes in fish species production, the study of pituitary structure and physiology becomes essential for aquaculture (Reinecke et al., 2006; Tanaka et al., 1995).

It is well established that the effect of environmental changes and external factors on fish reproduction are mediated through endocrine system control, since pituitary is involved in the endocrine system activity and has a central role in controlling gonadal activity. Seasonal changes are expected in the structure of pituitary in concomitant with growth phased, gonadal status and sexual maturation as confirmed by many studies, e.g. Assem, 2004; Chatterjee and Chakrabarti , 2014; Balci and Ikiz, 2017. The teleost pituitary distinguished by existence of adenohypophyseal cells directly innervated by branches of the neurohypophysis $(\mathrm{NH})$ (Holmes and Ball, 1974) and the adenohypophysis (AH) divided into three distinct regions containing different cell types producing hormone; these regions are rostral pars distalis (RPD), proximal pars distalis (PPD) and pars intermedia (PI) (Agulleiro et al., 2006).

The identification and distribution of the different cell types of the pituitary gland of teleosts have attracted attention of researches using histochemical, ultrastructural and immuno-cytochemical procedures (Mousa and Mousa, 1999; Assem, 2004; Cinquetti and Dramis, 2006; Chatterjee and Chakrabarti, 2014; Balci and Ikiz, 2017). Pituitary cell types can be differentiated by their morphology and by the hormones they secrete. In some studied species, one type of gonadotropin secreting cells (GTH) has been distinguished (Assem, 2004; Chatterjee and Chakrabarti, 2014).whereas, two GTH cell types have been described in other teleost species (Mousa and Mousa, 1999; Agulleiro et al., 2006). GTH cells have been studied throughout reproductive cycle, migration (Mukai and Oota, 1995) ontogeny and gonadal differentiation (Pandolfi et al., 2006; Grandi et al., 2014; Jesus et al., 2014), or even under experimental conditions (Golan et al., 2014).

The aim of this study is to identify and localize the diverse cell types in the pituitary gland of Diplodus sargus using histological, histochemical and electron microscope techniques. Moreover, to study the GTH cells density and distribution of the female pituitary all over maturity stages, relative to oocyte maturation and gonadosomatic indices; in order to give basic information on the reproductive biology for this Sparidae species. Electron microscopy was also used to provide GTH granulation according to function and seasonal changes. The identification of pituitary cell types will provide useful information for potential studies on the $D$. sargus pituitary gland function.

\section{MATERIALS AND METHODS}

\section{Fish sampling}

The samples in the present work were captured alive or obtained from the commercial catch, twice per month from Alexandria coast. The fish were sampled and, total length $(\mathrm{mm})$, total weight $(\mathrm{g})$ were recorded. The 110 specimens collected ranged in size from 14 to $32 \mathrm{~cm}$ and body weight between 103 to $618 \mathrm{~g}$. Fish were dissected to determine sex and maturity stage, gonads were removed, weighted to the nearest $\mathrm{g}$ and thoroughly examined. The shape, size and color of the gonads were recorded. A piece of the gonad was fixed in neutral buffered formalin. The maturity 
stages were identified macroscopically following the description of Nikolsky (1963) and Núñez and Duponchelle (2009), with some modifications.

\section{Gonadosomatic index (GSI)}

The GSI was calculated for each fish, according to the following formula:

GSI = (weight of gonad $\mathrm{x} 100) /$ Gutted weight of the fish

\section{Histological and Histochemical methods}

After dissection of the fish, the pituitary gland with a piece of the brain were fixed in $10 \%$ buffered formalin. After fixation, dehydration and embedding, consecutive median sagittal sections of the brain and pituitary were made at $5 \mu$ thickness. Different cell types were recognized according to the location of acidophilic and basophilic cells, and according to staining affinity and coloration of each type of cells. The size of gonadotroph cells was quantitatively detected by measuring the cell diameter using microscopic micrometer for nine sections (three different samples for each developmental stage per unit area). The pituitary sections were stained using various techniques as follows:

1. Herlant, in which acid permanganate oxidation, Alcian Blue (AB) combined with Periodic Acid Schiff's (PAS) and followed by Orange G (OG) as the counter stain (AB-PAS-OG) for display of thyrotrophs (deep blue), gonadotrophs (light blue), prolactin (pink), adrenocorticotropic cells (pink), somatotrophs (STH) (orange) and Melanocyte (MSH) (pink).

2. Periodic Acid Schiff's (PAS), Haematoxylin (H), Acid Fuchsin (AF) for the display of adrenocorticotropic cells (ACTH) and prolactin secreting cells (PRL) in pink red color, and gonadotrophs as magenta in color.

3. Masson's trichrome stain for demonstration of gonadotrophs and thyrotrophs as green if light green used or blue if aniline blue used as a counter stain, and ACTH, PRL,STH, MSH appear red in color.

\section{Electron microscope technique}

Pituitaries were immersed-fixed at $4^{\circ} \mathrm{C}$ in $4 \%$ glutaraldehyde and then in $1 \%$ osmium tetroxide at room temperature, than washed two times in Cacodylate buffer, dried out throughout a graded ethanol concentrations, cleared in propylene acid and embedded in polarbed 812 (polaron) epoxy resin. Ultra thin sections were made by using glass and diamond knives and uranyl acetate and lead citrate were used for staining.

\section{Statistical analysis}

Data of gonadotrophs cell size were presented as mean $\pm \mathrm{SE}$; means were compared using one way ANOVA followed by Tukey HSD for multiple comparisons. The analysis was carried out using the SPSS ${ }^{\circledR}$ version 22.0 package (SPSS 1998).

\section{RESULTS}

\section{ovarian cycle}

Maturity stages:

On the basis of seasonal changes encountered in the macroscopic features and gonadosomatic index (Fig. 1), the ovarian cycle of female can be explained as follow:-

\section{Immature stage:}

Ovaries were very thin and semi-transparent tubes with two tapering ends were detected. The average GSI value was about $0.37 \pm 0.17$ and this stage extended from June to August. 


\section{Maturing stage :}

Ovaries were enlarged in size, pinkish-red in colour and occupied about half of the body cavity. The average GSI values were about $0.43 \pm 0.15$ and this stage was recognized during the period August- October.

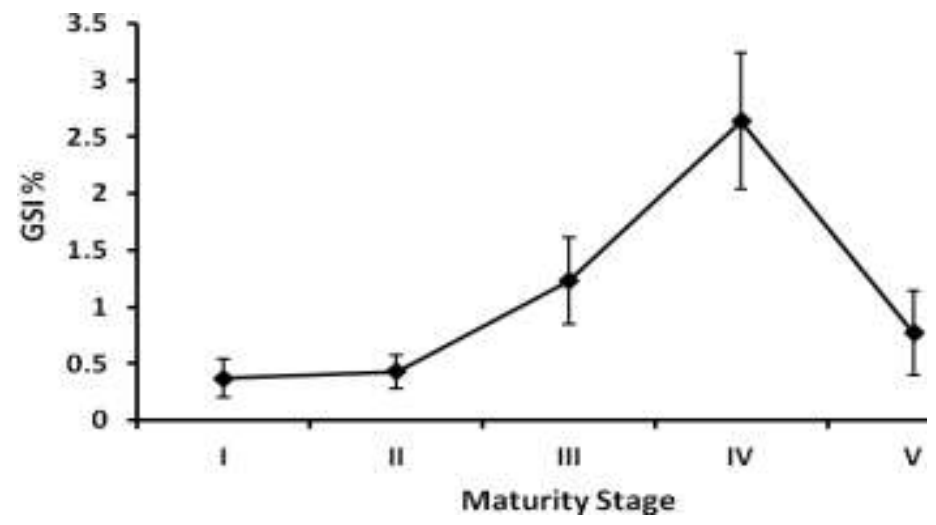

Fig. 1: Changes in gonadosomatic index (GSI) of D.sargus females with different maturity stages, values are presented as mean $\pm(\mathrm{SE})$

\section{Nearly ripe stage:}

Ovaries were yellowish in colour with visible oocytes as small granules, and size attained two third of body cavity. This stage was detected in November and December with an average GSI value of $1.23 \pm 0.38$.

\section{Ripe and Running stage :}

At this stage ovaries were at greatest growth in thickness and occupied the entire body cavity, with deep orange in coloration and with sufficient veins and arteries. This stage was detected from January to April, with an average GSI value of $2.64 \pm 0.6$.

\section{Spent stage:}

At the end of the spawning season, ovaries become partly spent. Ovaries were slight shrinkage due to the discharge of a considerable amount of ripe oocyte during spawning period, then ovaries severely shrunken, flaccid, collapsed and highly vascularized to be completely spent. This stage was detected from April to June, with average GSI values of $0.77 \pm 0.37$.

\section{The pituitary gland}

The pituitary gland of $D$. sargus is a leptobasic type with a whitish cone-shaped structure, suspended ventrally from the floor of the diencephalons of the brain. It is attached to the brain by a stalk (infundibular stalk).

Histochemicaly, in the mid sagittal section, the pituitary gland consisted of two main components: a- Neurohypophysis: consisted of nerve fibers, which extend below the pituitary stalk and penetrat deeply and ramified in the adenohypophysis (Fig. 2a), and b- Adenohypophysis: consisted of epithelial tissue, which comprised three main regions with no sharp separation between them; the rostral pars distails (RPD), the proximal pars distails (PPD) and the pars intermediata (PI), as shown in Figure (2a). The Different cell types of $D$. sargus, adenohypophysis have been identified on the basis of their staining affinities with various staining methods and categorized in two main groups: acidophils and basophils or may be chromophobe (Fig. 1b).

Pituitary gland sections of $D$. sargus were investigated microscopically and six different cell types were identified. These cells include Prolactin cells (PRL) and Adrenocorticotropic hormone secreting cells (ACTH) in the RPD. Somatotrop cells 
(STH), Melanocyte stimulating hormone secreting cells (MSH), Gonadotrops (GTH) and Thyrotrops (TSH) were present in the RPD, PPD and PI regions.

\section{Prolactin hormone secreting cells (PRL).}

These cells are small in size with asymmetrical shape and have rounded nuclei situated against the neurohypophysis among the ACTH cells. Prolactin cytoplasm exhibited positive reaction with acid fuchsin but negative to PAS, AB and aniline blue stains. However, these cells did not display any changes towards the annual reproductive cycle (Fig. $2 \mathrm{c} \& \mathrm{~d}$ ).

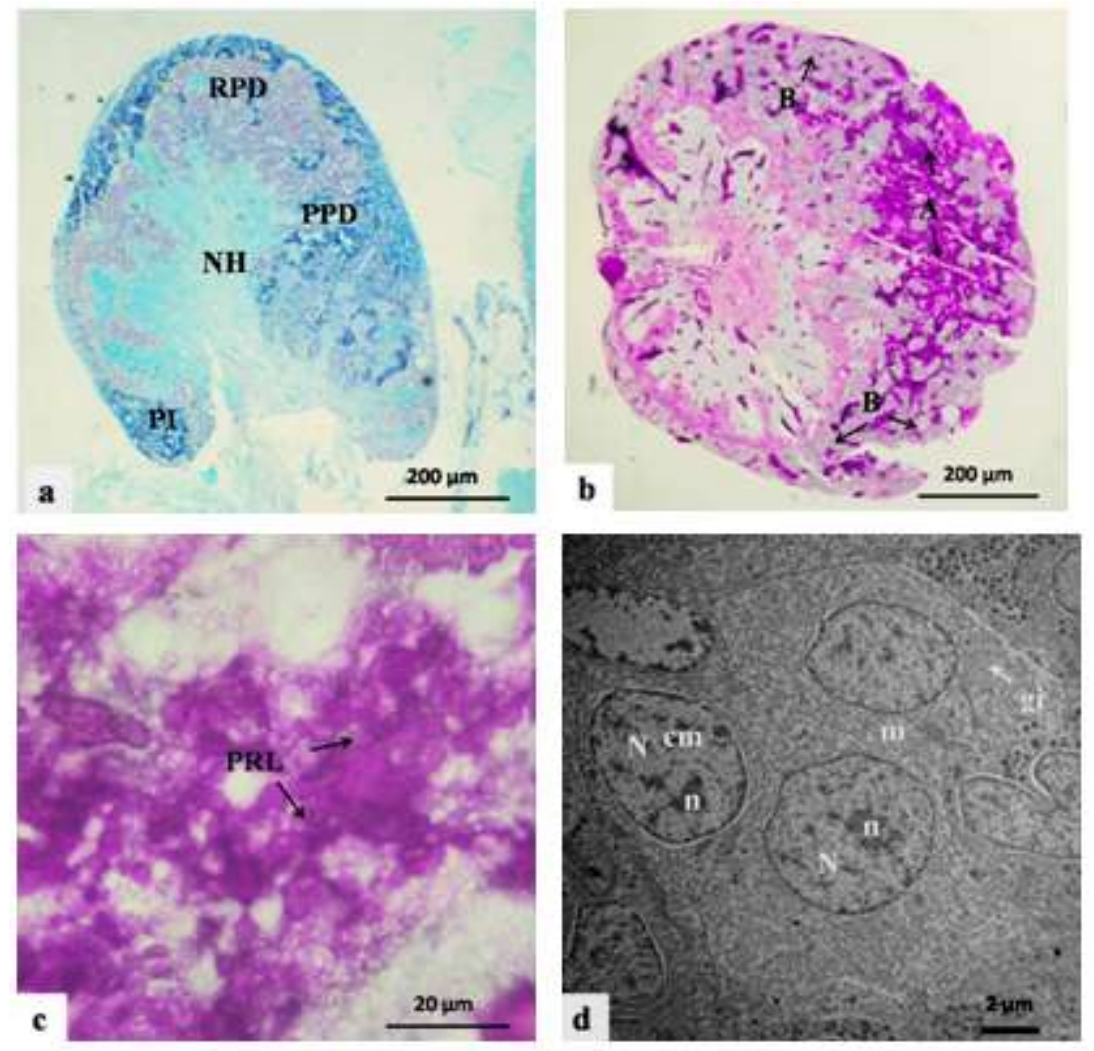

Fig. 2: (a) Midsagittal section of the pituitary gland of female Diplodus sargus stained with Herlant technique showing rostral pars distails (RPD), proximal pars distails (PPD) and pars intermedita (PI) which comprise the adenohypophysis and neurohypophysis (NH). (b) Sagittal section of the pituitary gland of ripe and running female stained with Periodic acid (PAS), hematoxylin and acid Fuchcine (AF) acidophilic cell type (red) and (B) basophilic cell type (light purple). (c) Periodic acid (PAS), hematoxylin and acid Fuchcine (AF) staining showing prolactin cells (PRL).(d) EM of (PRL) cells at prespawning stage showing nucleus (N), nucleolus (n), golgi body (gi), mitochondria $(\mathrm{m})$ and chromatin material $(\mathrm{cm})$.

\section{Adrenocorticotropin hormone secreting cells (ACTH):}

ACTH cells appear like cords bordering PRL cells and situated amongst PRL cells and the neurohypophysis. They are large in size, elongated in shape, with small eccentric nuclei. These cells have no affinity for $\mathrm{AB}$ or aniline blue with strong affinity to acid fuchsin (acidophilic cell type) (Fig. 3 a,b,c).

\section{Melanocyte stimulating hormone cells (MSH).}

MSH cells were generally round in shape with rounded or indented nucleus centrally located in the cells. These cells were displayed acidophilic affinity and occupy the PPD and RPD regions. MSH cells positively stained with AB- PAS-OG, and displayed magenta color. MSH cells displayed no change in their characteristics throughout the year (Fig. 3d). 

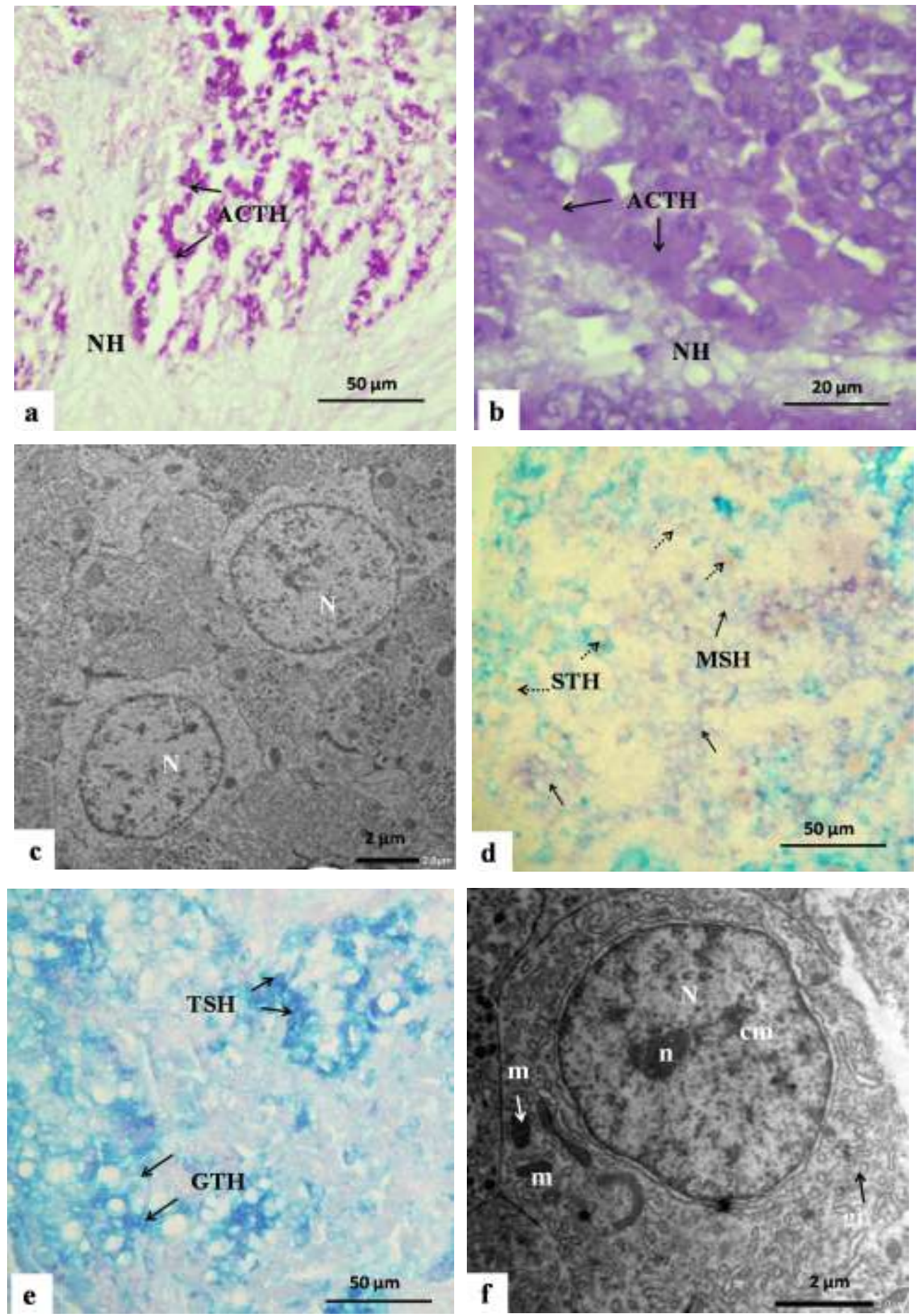

Fig. 3: (a) PAS- hematoxylin -AF stain showing adrenocorticotropic cells (ACTH) stained red colour (X400), (b) magnification of adrenocorticotropic cells (ACTH) closed to neurohypophysis (NH) stained with hematoxylin and eosin (HE) (x1000). (c) EM of ACTH, nucleus (N). (d) PAS-AB- OG staining showing somatotrops (STH) with yellow orange color, melanotrops (MSH) stained pink with gonadotrops (GTH) stained light blue (X400).(e) Herlent staining showing gonadotrops (GTH) stained light blue and thyrotrops (TSH) stained deep blue (X400).(f) EM of thyrotrops (TSH) showing nucleus (N), nucleolus (n), mitochondria (m) and chromatin material $(\mathrm{cm})$. 


\section{Somatotropin hormone secreting cells (STH):}

The fourth acidophilic cell type is STH. They are found combined with the GTH cells in the RPD and PPD region, and could not be detected in the PI region. These cells were frequently rounded or ellipsoid, with oval or irregular eccentric nuclei location. These acidophilic cells type are stained orange with AB- PAS-OG (Fig. 3d).

\section{Gonadotrophic hormone secreting cells (GTH):}

GTH occupied most of the PPD region and extend to RPD. Aggregations of GTH cells were also observed in the PI region. These basophilic cells had uneven shapes and sizes and with spherical nuclei that were eccentric in location. Herlant gave blue colour for GTH and TSH cells as shown in Figure 3e. The basophilic granules in the GTH cells varied in number, size and intensity with the season. GTH cells stained with aniline blue or light green when masson's stain used.

\section{Thyrotropin hormone secreting cell (TSH):}

TSH cells were present between RPD and PI in the border cortex of adenohypophysis. These cells appeared either angular or elongated in shape. These cells are basophilic and reacted with Herlant and display intense blue color (Fig. 3e \& f) and exhibited dark blue colour in the cytoplasm with aniline blue of masson's stain, TSH cells did not vary with the season.

\section{Seasonal changes in the gonadotropin cells in relation to ovarian maturation}

Annual changes in the GTH cell diameters and their cytoplasm granulation were detected using histochemical and ultrastructural methods. The GTH cell diameter to each ovarian developmental stage is indicated in Table (1). During the immature and maturing stages (June- October), pituitaries displayed GTH cells mainly in the PPD with a few in number in the RPD, while no cells were detected in the PI region.

Table 1: GTH cell diameter in female D.sargus in relation to different stage of maturity, Values represent means $\pm(\mathrm{SD})$ values not shearing the same superscript are significantly different $(\mathrm{P}<0.05)$.

\begin{tabular}{|c|c|c|}
\hline Months & Stage of maturity & GTH cell diameter $(\boldsymbol{\mu m})$ \\
\hline June- August & Immature & $5.64 \pm 0.62^{\mathrm{b}}$ \\
\hline August- October & Maturing & $6.37 \pm 1.2^{\mathrm{b}}$ \\
\hline November - December & Nearly ripe & $12.48 \pm 0.57^{\mathrm{a}}$ \\
\hline January - April & Ripe and running stage & $11.2 \pm 1.6^{\mathrm{a}}$ \\
\hline April - June & Spent & $5.3 \pm 0.7^{\mathrm{b}}$ \\
\hline
\end{tabular}

The diameter of GTH for immature stage averaged $5.64 \pm 0.62 \mu \mathrm{m}$ and $6.37 \pm$ $1.2 \mu \mathrm{m}$ for maturing stage. A few granules appear in the GTH cells, during these two stages, various marked vacant areas were detected between GTH cells (Figs. 4 a \&b).

During nearly ripe stage (November - December), the vacant areas between cells decreased and the average GTH cell diameter reached it maximum value of $12.48 \pm 0.57 \mu \mathrm{m}$ as indicated in Table (1). A slight increase in the staining affinity of GTH cells was detected at this stage due to active accumulation of granules (Fig. 4c). GTH cells were sited mainly in the PPD region with small number detected in PI region. Ultrastructure of GTH cells indicated their activity at this stage by increasing cytoplasmic granulation and nuclear chromatin density with the maximum amount of granulation (Figs. 4 d\&e). 

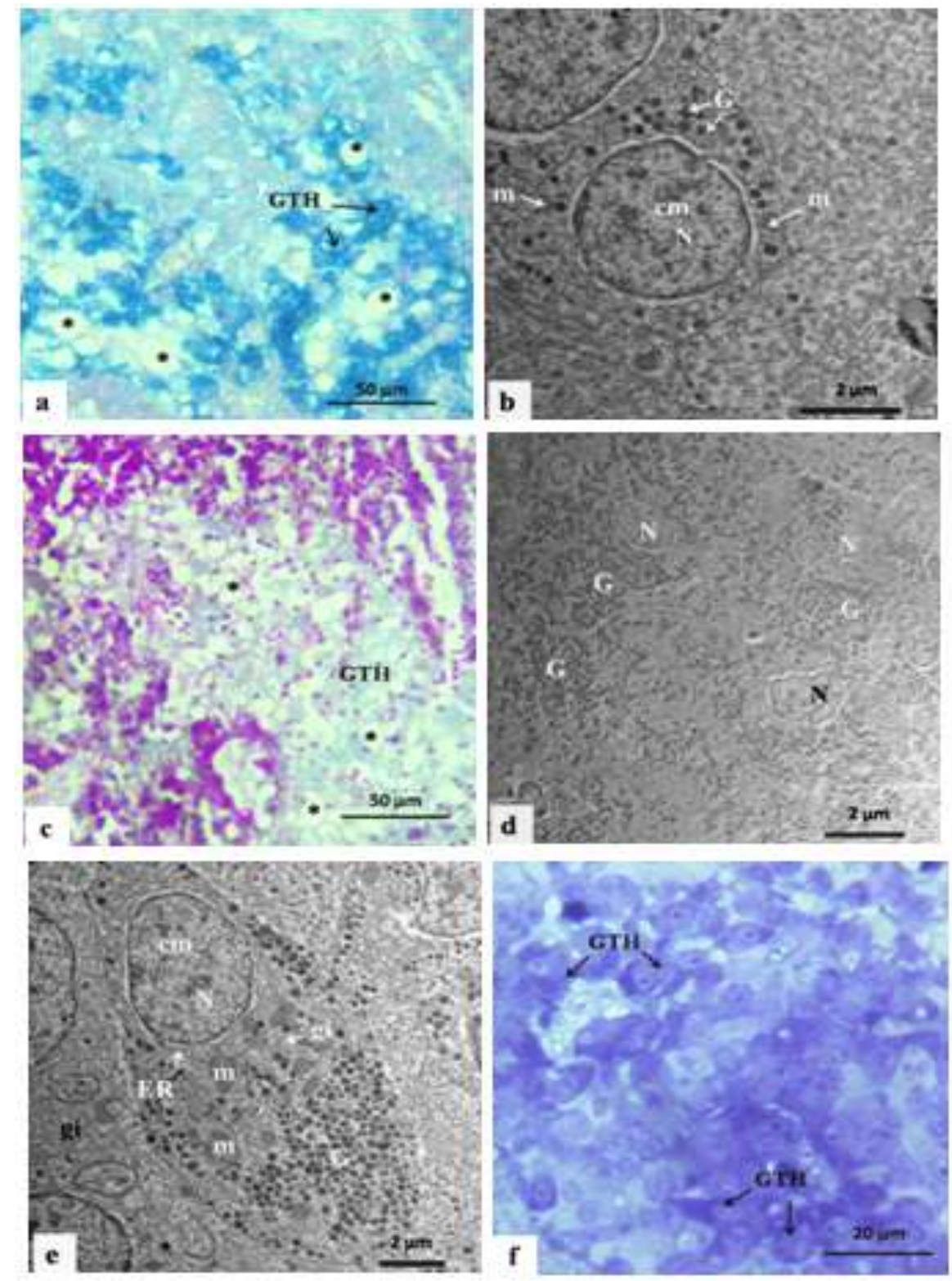

Fig. 4: (a) Sagittal section of the pituitary gland of female D. sargus at maturing stage stained with Herlant technique showing: spaces (*) between the blue basophilic (GTH) and (TSH) in PPD region (X400). (b) EM of the pituitary gland at maturing stage stained with lead citrate and uranyl acetate showing gonadotropic cells with moderate their granulation $(\mathrm{G})$. (c) Pituitary at nearly ripe stage stained with masson's trichrome showing basophilic gonadotropic cells with few spaces (*) between cells. (d) EM of Pituitary at nearly ripe stage showing gonadotropic cells with intense granulation. (e) EM magnification of gonadotropic cell with maximum size and active organelles and highest granulation. (f) Pituitary at ripe and running stage showing gonadotroph (GTH) stained with toluidine blue (X1000). nucleus (N), nucleolus (n), granulation $(\mathrm{G})$, golgi body (gi), endoplasmic reticulum (ER) and chromatin material $(\mathrm{cm})$.

During the breeding time (ripe and running stage), which extends from January to April, slight decrease in the average diameters of GTH cells was noticed (11.2 \pm $1.6 \mu \mathrm{m})$ as indicated in Table (1). GTH cells were widely distributed in all regions with no vacant areas between the cells (Fig. 4f), cells were high in number with high affinity to staining (Fig. 5a). At the spawning period, the GTH ultrastructural secreting activity was indicated by the slight decrease in nuclear density and cytoplasmic granulation, in addition to the presence of endoplasmic reticulum and the increased number of mitochondria in cytoplasm of GTH cells (Fig. 5b). 
During the spent stage (from April to June), the GTH cells stained very weakly indicating the presence of few granules (low activity). A few number of GTH cells were granulated, with an average diameter of about $5.3 \pm 0.7 \mu \mathrm{m}$. Most of the GTH cells became vacuolated (Fig. 5c), and the GTH cells were inactive with decrease in average number and diameters during the spent period. Ultrastructure of GTH cells was indicated by decreased cytoplasmic granulation and nuclear chromatin density (Fig. 5d).
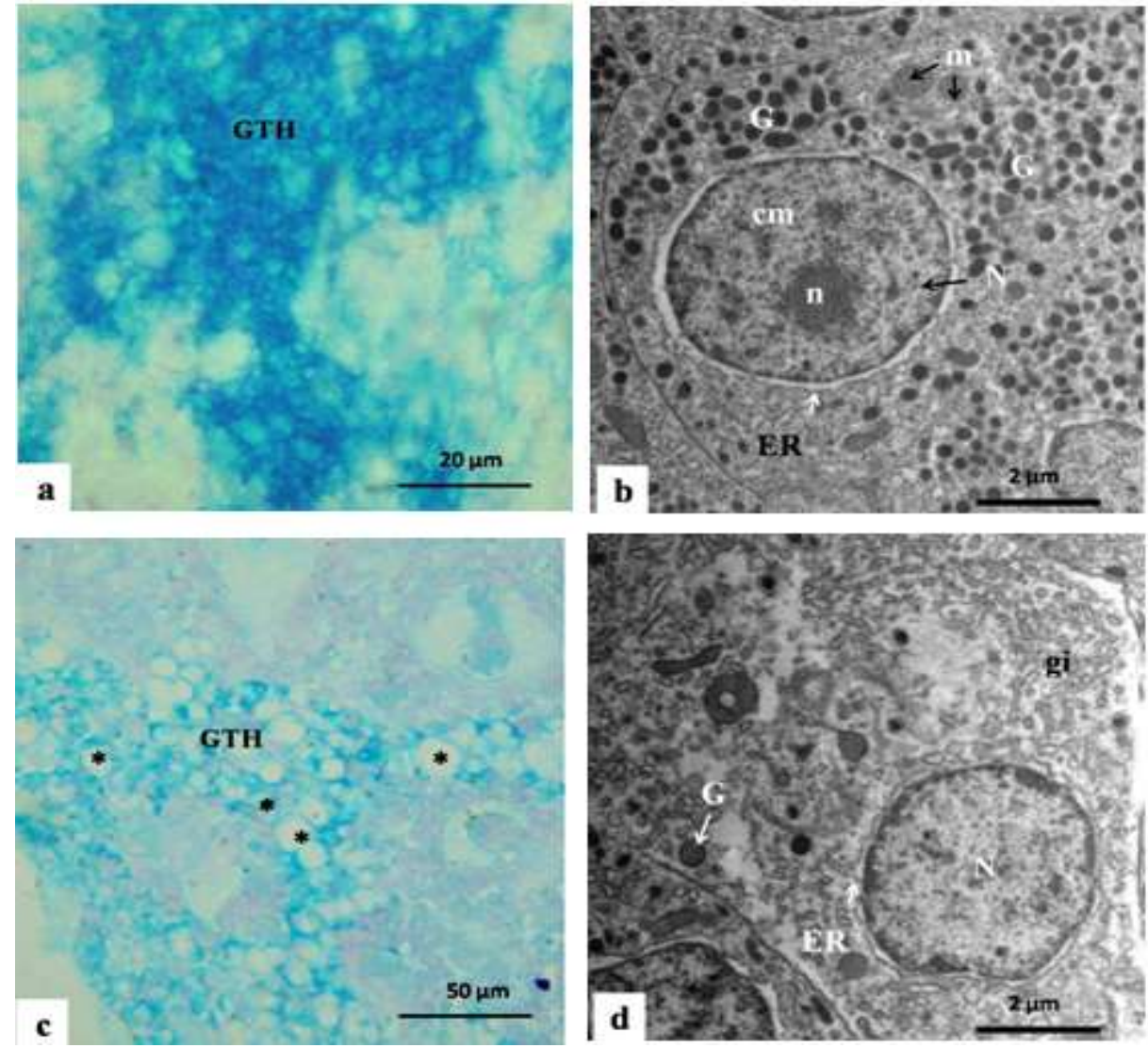

Fig. 5: (a) magnified gonadotrophic cells (GTH) with intense staining and no spaces at ripe and running stage stained with Herlent (X1000). (b) EM of active gonadotrophic cell with granulation (G). (c) Pituitary gland of female D. sargus at spent stage stained with Herlant technique showing many spaces (*) between gonadotrophic cells (GTH). (d) EM of gonadotrophic cell at spent stage showing minimum amount of granulation $(\mathrm{G})$ and small cell size. nucleus $(\mathrm{N})$, nucleolus $(\mathrm{n})$, granulation $(\mathrm{G})$,golgi body (gi), endoplasmic reticulum (ER) and chromatin material $(\mathrm{cm})$.

\section{DISCUSSION}

In the current study, the spawning of female D. sargus occurred from January to April. During this period, the GSI reported maximum values. This stage was previously reported as from March to June in Azores (Morato et al., 2003), and from March to May in the Gulf of Tunis (Mouine et al., 2007); explaining that the onset and length of spawning time in the seabream is related to sea water temperatures variations.

As in the majority of teleost fish, the pituitary gland of D. sargus is of the leptobasic type i.e. the neurohypophysis has well-developed infundibular stalk and the adeohypophysis is cone shaped. The neurohypophysis in D. sargus consisted of nerve fibers, which extended below the pituitary stalk. Similar observations were 
reported in a number of teleost species as for: Dicentrarachus labrax (Assem, 2004), Mystus vittatus (Chatterjee and Chakrabarti, 2014); Pagellus erythrinus (Balci and Ikiz, 2017).

In the present study, the histochemical techniques with the different staining reactions of the cytoplasm content recognized six cell types in the adenohypophysis of D.sargus. Comparable cell types were identified in many studied teloets (Assem, 2004; Chatterjee and Chakrabarti, 2014; Balci and Ikiz, 2017). More pituitary cell types were acknowledged in other teleost such as Barbus barbus (Toubeau et al., 1991) and Odontesthes bonariensis (Vissio et al., 1997), while five cell types were recognized in Rhabdosargus haffara (Assem and El-Boray, 2001). The present work identified only one type of gonadotropin cell in D.sargus pituitary, similarly SeguraNoguera et al. (2000) reported this observation earlier in cultured in D. sargus.

The gonadotropin cells displayed variation in size and pituitary regions in response to seasonal reproductive cycle. It was declared that gonadotropin cells in proximal pars distalis are detected only in adult fish and they become larger during the maturation period of the gonads (Massoud et al., 1983; Balci and Ikiz, 2017). Fish pituitary GTH cells have been extensively investigated throughout the gonadal development and reproduction of quite a lot of species as cells secreting Fsh and Lh during early of stage gametogenesis and final ovulation and spermiation (Agulleiro et al., 2006; Schulz et al., 2010).

In the present study, the vacuolar spaces between gonadotropin cells for immature and spent stages were observed more than through spawning time, while secretion granules of gonadotropin cells spread over a great area of the cell during spawning period. These variation in the granulation amount was reported for many studied species (Assem, 2004; Vongvatcharanon et al., 2005; Chatterjee and Chakrabarti, 2014; Balci and Ikiz, 2017).

In this study, the ultrastructural features of the gonadotropin cells are typical model of protein-secreting endocrine cells, in which organelles which are essential for hormone synthesis, like Golgi body and secretory vesicles closed to the cell membrane were identified in the gonadotropin cell cytoplasm and variable number of basophilic/PAS secretory granules (Agulleiro et al., 2006).

In the present study, no noteworthy changes of the activity and size of ACTH, PRL, somatotropic (STH) cells, TSH and melanocyte cells (MSH) were observed at different reproductive stages. Similar results were reported for Notopterus notopterus (Chakrabarti and Choudhury, 2015), Dicentrarachus labrax (Assem, 2004), Mystus vittatus (Chatterjee and Chakrabarti, 2014); Pagellus erythrinus (Balci and Ikiz, 2017). Conversely to the present results, MSH cell displayed variation in its amount along with the phase of the sexual cycle of $D$. sargus females but not males (Ferrandino et al., 2000).

In conclusion, the structure of pituitary gland of the D. sargus female is similar to the pituitary gland of other teleots. Histochemicaly, the acidophilic, basophilic cells cells are categorized into six cell types, which are similarly described in other teleost fishes. Moreover, the GTH cells display seasonal variation in its size and the amount of granulation in relation to the different maturity stages and GSI value, with maximum size and granulation before and during spawning time, which confirming their endocrine role in manipulating reproduction for adult female fish.

\section{REFERENCES}


Agulleiro, B.; Garcia-Hernandez, M.P. and Garcia Ayala, A. (2006). Teleost Adenohypophysis: morphofunctional and development aspects. In: Reinecke MP, Zaccone G, Kapoor BG (eds) Fish endocrinology, vol 1. Science Publishers, Enfield, pp 289-440

Assem, S.S. (2004). Histochemical studies, cell type distribution and seasonal variation of gonadotropin cells in pituitary gland of female Dicentrarchus labrax in relation to maturation of gonads. Egyptian Journal of Aquatic Research, 30:374-389.

Assem, S.S. and El-Boray, K.F. (2001). Cell type distribution and comparative studies of gonadotropin cells in the pituitary gland of female Rhabdosargus haffara reared in saline and brackish water. Egyptian German Society of Zoology, 27:109-134.

Balci, B. and Ikiz, B.R. (2017). Light and electron microscopic examination of the pituitary gland of common Pandora (Pagellus erythrinus L., 1758), Int J Fish Aqua Stud., 5(6):97-102

Chakrabarti, P. and Choudhury, S.H. (2015). Morpho-Histological architecture of various cells with special emphasis on the seasonal variations of gonadotrophs in the pituitary gland of Notopterus notopterus (Pallas, 1769) in relation to testicular maturation. Journal of Entomology and Zool. Studies, 3(2): 297-304.

Chatterjee, N. and Chakrabarti, P. (2014). Distributional pattern of different cells with special emphasis on the seasonal variations of gonadotrophs in the pituitary gland of Mystus vittatus (Bloch) in relation to testicular activities. Int J Fish Aqua Stud., 2:79-87.

Cinquetti, R. and Dramis, L. (2006). Identification and localization of hormoneproducing cells in the pituitary of male Padogobius martensi (Pisces, Gobiidae): a histochemical and immunocytochemical study. J Fish Biol., 68:235-250

Fish and Agriculture Organisation (FAO) (2014). The State of World Fisheries and Aquaculture 2014. FAO, Rome, p. 223.

Ferrandino, I.; Pica, A. and Grimaldi, M.C. (2000). Immunohistochemical detection of $\mathrm{ACTH}$ and MSH cells in the hypophysis of the hermaphroditic teleost, Diplodus sargus. Eur J Histochem., 44:397-406

Golan, M.; Biran, J. and Levavi-Sivan, B. (2014). A novel model for development, organization, and function of gonadotropes in fish pituitary. Front Endocrinol., $5: 182$

Grandi, G.; Marchetti, M.G.; Lanzoni, M. and Chicca, M. (2014). Immunocytochemical and ultrastructural identification of adenohypophyseal cells in Ctenopharyngodon idella (Cypriniformes: Cyprinidae) during gonadal differentiation. Fish Physiol Biochem,. 40:1115-1139

Holmes, R. L. and Ball, J. N. (1974). The Pituitary Gland: A Comparative Account. Cambridge University Press, Cambridge

Jesus, L.W.O.; Chehade, C.; Costa, F.G. and Borella, M.I. (2014). Pituitary gland morphogenesis and ontogeny of adenohypophyseal cells of Salminus brasiliensis (Teleostei, Characiformes).Fish Physiol Biochem., 40:897-909

Massoud, A.A.; Simco, B.A. and Davis, K.B. (1983). Annual changes in basophilic cell types in the pituitary gland of channel catfish, Ictalurus punctatus. Comparative Biochemistry and Physiology, 74:513-520.

Morato, T.; Afonso, P.; Lourinho, P.; Nash, R.D.M. and Santos, R.S. (2003). Reproductive biology and recruitment of the white seabream in the Azores. J. Fish Biol., 63: 59-72. 
Mouine, N.; Francour, P.; Ktari, M.H. and Chakroun-Marzouk, N. (2007). The reproductive biology of Diplodus sargus sargus in the Gulf of Tunis (central Mediterranean). Sci Mar., 71:461-469.

Mousa, S.A. and Mousa, M.A. (1999). Immunocytochemical and histological studies on the hypophyseal-gonadal system in the freshwater Nile Tilapia, Oreochromis niloticus (L), during sexual maturation and spawning in different habitats. J Exp Zool. 284: 343-54.

Mukai T. and Oota Y. (1995). Histological changes in the pituary, thyroid gland and gonads of the fourspine sculpin (Cottus kakiza) during downstream migration. Zool. Sci., 12: 91-97.

Nikolsky, G. (1963). The Ecology of Fishes. Academic Press, London, UK, 352pp.

Núñez, J. and Duponchelle, F. (2009). Towards a universal scale to assess sexual maturation and related life history traits in oviparous teleost fishes. Fish Physiology and Biochemistry, 35 (1): 167-180.

Pandolfi, M.; Lo Nostro, F.L.; Shimizu, A.; Pozzi, A.G.; Meijide, F.J.;Vazquez, G.R. and Maggese, M.C. (2006). Identification of immunoreactive FSH and LH cells in the cichlid fish Cichlasoma dimerus during the ontogeny and sexual differentiation. Anat Embryol., 211:355-365.

Reinecke, M.; Zaccone, G.and Kapoor, B.G. (eds) (2006). Fish endocrinology, vol 1. Science Publishers, New Hampshire

Schreibman, M.P. (1986). Pituitary gland. In: Pang PKT, Schreibman MP (eds) Vertebrate endocrinology: fundamentals and biomedical implications, morphological con siderations, vol 1. Academic Press, New York, pp 11-55

Schulz, R. W.; de Franc,a, L. R.; Lareyre, J.J.; LeGac, F.; Chiarini-Garcia, H.; Nobrega, R. H. and Miura, T. (2010). Spermatogenesis in fish. Gen Comp Endocrinol., 165: 390-411.

Segura-Noguera, M.M.; Laiz-Carrion, R.; del Rio,M.P. and Mancera, J.M. (2000). An immunocytochemical study of the pituitary gland of the white seabream (Diplodus sargus) Histochem. J., 32:733-742.

Tanaka, M.; Tanangonan. J. B.; Tagawa, M.; de Jesus, E. G.; Nishida, H.; Isaka ,M.; Kimura, R. and Hirano, T. (1995). Development of the pituitary, thyroid and interregnal glands and applications of endocrinology to the improved rearing of marine fish larvae. Aquaculture, 135: 111-126

Toubeau, G.; Poilve, A.; Saras, E.; Nonclercq, D.; De Moor, S.; Seckers, J.F.; DessyDoize, C. and Heuson-Stiennon, J.A.(I991). Immunocytochemical study of cell types distribution in the pituitary gland of Barbus barbus (Teleostei, Cyprinidae).Gen. Comp. Endocrinol., 83:3.

Veiga, P.; Ribeiro, J.; Gonçalves, J.M.S. and Erzini, K. (2010). Quantifying recreational shore angling catch and harvest in southern Portugal (north-east Atlantic Ocean): implications for conservation and integrated fisheries management. J. Fish Biol., 76: 2216-2237.

Vissio, P. G.; Somoza, G. M.; Maggese, M. C.; Paz, D. A., and Strüssmann, C. (1997). Structure and cell type distribution in the pituitary gland of pejerrey Odontesthes bonariensis. Fisheries Sci., 63: 64-68.

Vongvatcharanon, U.; Kirirat, P.; Suwanjarat, J. and Boonyoung, P. (2005). Alteration of gonadotrophs in the pituitary gland during the annual reproductive cycle of the adult female sand goby (Oxyeleotris marmoratus). J Sci Technol., 27:437-445. 


\section{ARABIC SUMMARY}

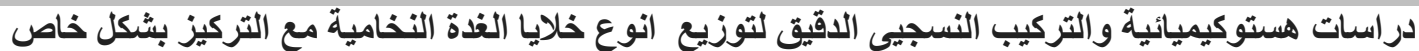

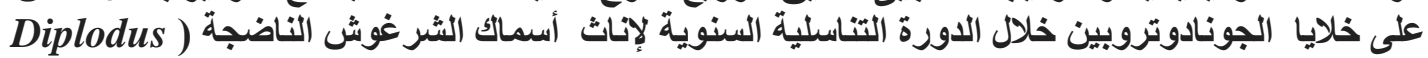
(sargus

$$
\begin{aligned}
& \text { رانيا فهمي خضر إسماعيل - ريهام محمد قدرى نجم الإياء }
\end{aligned}
$$

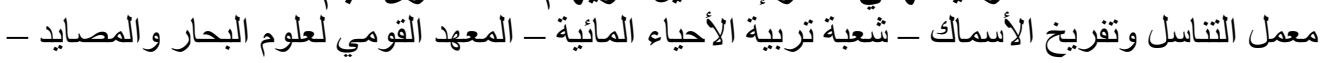

$$
\begin{aligned}
& \text { الإسكندرية. }
\end{aligned}
$$

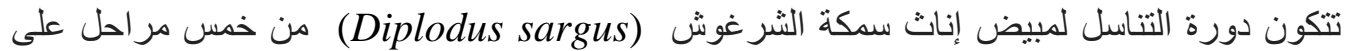

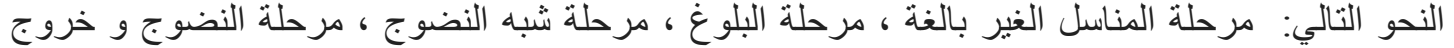

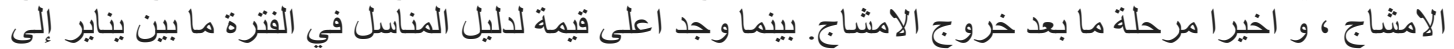

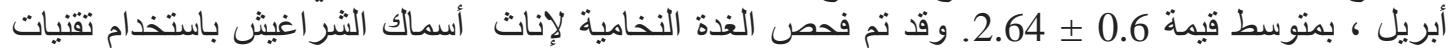

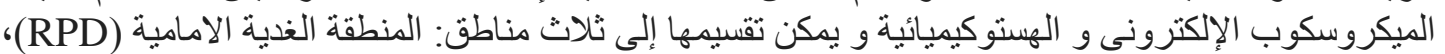

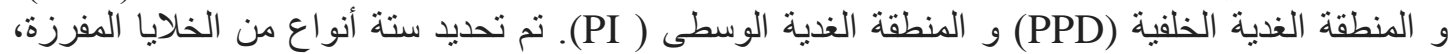

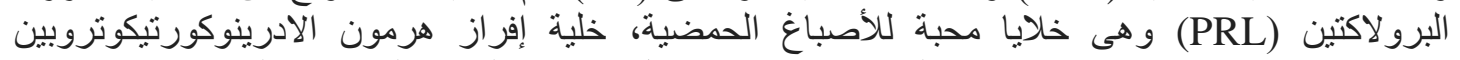

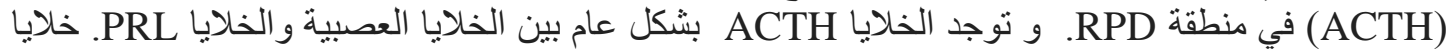

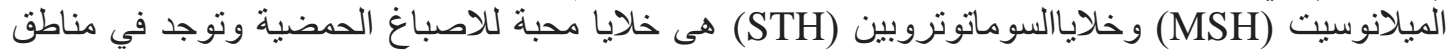

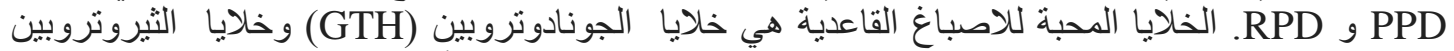

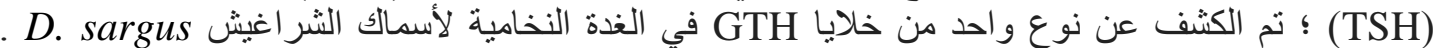

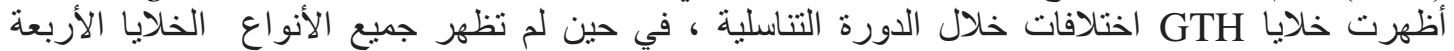

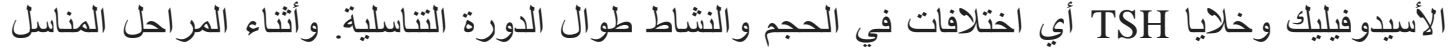

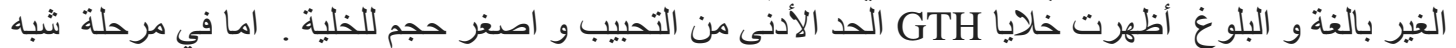

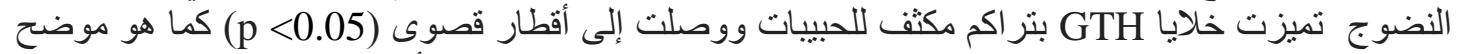

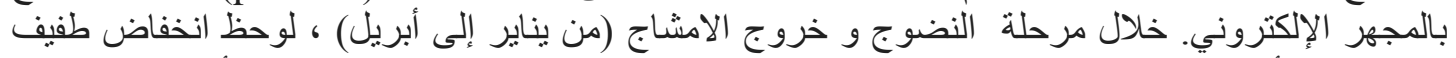

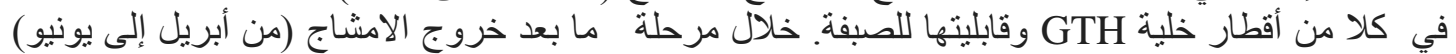
اظظهرت خلايا GTH صبغة باهنة مع وجود فجو التهات بين الخلايا. 